\title{
GAMBARAN PENGETAHUAN PASIEN DIABETES MELITUS TIPE 2 TENTANG SENAM KAKI PADA DIABETES DI LINGKUNGAN XXIV PEKAN LABUHAN KECAMATAN MEDAN LABUHAN
}

\author{
Meriani Herlina \\ Staf Pengajar Prodi S1 Keperawatan STIKes Imelda, Jalan Bilal Nomor 52 Medan \\ Email: siahaanmeriani@yahoo.co.id
}

\begin{abstract}
ABSTRAK
Diabetes Melitus Tipe 2 terjadi akibat penurunan sensitivitas terhadap insulin (resistensi insulin) atau akibat penurunan jumlah produksi insulin. Diabetes Melitus Tipe 2 sering ditemukan pada usia dewasa obesitas meskipun dapat terjadi pada semua umur, ketosis jarang terjadi kecuali dalam kedaan stres atau mengalami infeksi. Senam Kaki adalah kegiatan yang dilakukan oleh pasien DM untuk mencegah terjadinya luka dan membantu melancarkan peredaran darah pada kaki.Data organisasi kesehatan dunia World Health Organization (WHO, 2009), Indonesia menempati urutan ke enam di dunia. Adapun jenis penelitian ini adalah deskriptif, dan metode pengambilan sampel Non Probability Sampling dengan tehnik Total Sampling dengan sampel sebanyak 10 sampel dengan tekhnik kuesioner menggunakan 15 pertanyaan. Dari hasil penelitian ditemukan bahwa mayoritas Pengetahuan Pasien Diabetes Melitus Tipe 2 Tentang Senam Kaki di Lingkungan XXIV Pekan Labuhan Kecamatan Medan Labuhan Tahun 2017 berpengetahuan kurang berjumlah 5 responden (50\%), berdasarkan umur mayoritas berumur > 60 tahun keatas sebanyak 3 responden (30\%), mayoritas berpendidikan SD sebanyak 4 responden (40\%), mayoritas yang tidak memperoleh informasi sebanyak 6 responden (60\%). Dari data diatas dapat disimpulkan bahwa mayoritas responden yang ada di Lingkungan XXIV Pekan Labuhan Kecamatan Medan Labuhan mayoritas berpengetahuan kurang untuk itu disarankan kepada responden agar dapat meningkat pengetahuan tentang diabetes mellitus dan senam kaki dengan cara memperoleh informasi dari tenaga kesehatan, media elektronik ataupun media cetak. Dan diharapkan kepada tim medis agar dapat bekerja sama dengan klien dalam memperhatikan penderita DM dengan mengenalkan atau mengajarkan senam kaki diabetik yang sangat bermanfaat untuk melancarkan sistem peredaran darah pada kaki untuk mencegah luka ganggren.
\end{abstract}

Kata kunci : Pengetahuan, Diabetes Melitus Tipe 2, Senam Kaki

\section{PENDAHULUAN}

Diabetes Melitus merupakan suatu penyakit kronik yang kompleks yang melibatkan kelainan metabolisme karbohidrat, protein dan lemak dan berkembangnya komplikasi makrovaskuler dan neurologis (Sukarmin, 2008).

Diabetes Melitus merupakan suatu kelompok penyakit yang ditandai dengan kadar glukosa yang melebihi normal (hiperglikemia) akibat tubuh kekurangan insulin baik absolut maupun relatif. Tingkat kadar glukosa darah menentukan apakah seorang menderita DM atau tidak (Hasdianah, 2012).

Penyakit Diabetes Melitus (DM) merupakan penyakit degeneratif yang memerlukan upaya penanganan yang tepat dan serius karena dapat menimbulkan komplikasi seperti: penyakit jantung, gagal ginjal, dan kerusakan sistem saraf.

Beberapa jenis DM terjadi karena interaksi yang kompleks dari lingkungan, genetik, dan pola hidup sehari-hari. Diabetes mellitus (DM) dibagikan kepada beberapa kelas yaitu diabetes mellitus (DM) tipe 1, diabetes mellitus (DM) tipe 2, Diabetes Melitus (DM) tipe lain, dan diabetes mellitus (DM) kehamilan (American Diabetes Association, 2010).

Berdasarkan data yang diperoleh dari Dinas Kesehatan Kota Medan tahun 2009 terlihat jumlah kasus yang terbanyak setelah hipertensi adalah kasus diabetes melitus. Hingga September 2009 ada 10347 penderita diabetes melitus yang berobat ke 39 Puskesmas di kota Medan. Data tersebut menunjukkan bahwa penderita diabetes melitus di Kota Medan sangat tinggi (STPTM Dinas Kesehatan Kota Medan, 
2009).Menurut (Wibisono, 2009) yang menjadi Ketua Persatuan Diabetes Indonesia, senam kaki ini berpengaruh untuk memperbaiki sirkulasi darah.Dari pengamatan di Rumah Sakit. Dr. Oen Solo Baru pada tanggal 7 Mei 2007 banyak penderita Diabetes Melitus yang mengikuti senam kaki, karena disamping menyehatkan tubuh juga sangat memungkinkan untuk dapat mengikutinya. Dia juga pernah melakukan penelitian tentang senam ini pada tahun 2009. Tetapi pada penelitian tersebut memfokuskan pada lansia saja. Pada tahun yang sama juga melakukan penelitian tentang pengaruh senam kaki dalam mencegah kaki diabetik, kemudian (Julian, 2010) melakukan penelitian tentang pengaruh senam kaki terhadap peningkatan sirkulasi darah kaki pada pasien DM di RSUP Haji Adam Malik Medan yaitu ratarata sirkulasi darah kaki sebelum dilakukan senam kaki 0,94 mmHg dan sesudah dilakukan senam kaki terjadi peningkatan sirkulasi darah kaki menjadi 1,90 mmHg.

Neuropati perifer atau kerusakan saraf merupakan komplikasi serius dari diabetes. Data terbaru menunjukkan bahwa satu dari lima orang dengan diabetes (20\%) memiliki neuropati perifer. Resiko neuropati perifer adalah sekitar 2 kali lipat lebih tinggi dibandingkan orang tanpa diabetes. Kombinasi neuropati perifer dengan masalah yang terkait dengan suplai darah ke kaki dapat menyebabkan ulkus kaki dan penyembuhan luka lambat. Infeksi ini dapat mengakibatkan luka amputasi, 40-70\% dari seluruh amputasi ekstremitas bawah disebabkan oleh Diabetes Melitus.

Salah satu komplikasi penyakit diabetes melitus yang sering dijumpai adalah kaki diabetik (diabetic foot), yang dapat bermanifestasikan sebagai ulkus, infeksi dan ganggren dan artropati Charcot.Ada dua tindakan dalam prinsip dasar pengelolaan diabetic foot yaitu tindakan pencegahan dan tindakan rehabilitasi.Tindakan rehabilitasi meliputi program terpadu yaitu evaluasi tukak, pengendalian kondisi metabolik, debridemen luka, biakan kuman, antibiotika tepat guna, tindakan bedah rehabilitatif dan rehabilitasi medik.Tindakan pencegahan meliputi edukasi perawatan kaki, sepatu diabetes dan senam kaki (Yudhi, 2009).

Gerakan-gerakan senam kaki ini dapat memperlancar peredaran darah di kaki, memperbaiki sirkulasi darah, memperkuat otot kaki dan mempermudah gerakansendi kaki. Dengan demikian diharapkan kaki penderita diabetes dapat terawat baik dan dapat meningkatkan kualitas hidup penderita diabetes (Anneahira, 2011). Dari sudut ilmu kesehatan, tidak diragukan lagi bahwa olah raga apabila dilakukan sebagaimana mestinya menguntungkan bagi kesehatan dan kekuatan pada umumnya.Selain itu telah lama pula olah raga, digunakan sebagai bagian pengobatan diabetes melitus namun tidak semua olah raga dianjurkan bagi pengidap diabetes melitus (bagi orang normal juga demikian) karena dapat menimbulkan hal-hal yang tidak diharapkan.Olahraga, yang dilakukan adalah olahraga yang terukur, teratur, terkendali dan berkesinambungan.Frekuensi yang dianjurkan adalah 3-5 kali perminggu. Intensitas yang dianjurkan sebesar 40-70\% (ringan sampai sedang).Salah satu jenis olah raga, yang dianjurkan terutama, pada penderita, usia, lanjut adalah senam kaki (Akhtyo, 2009).

Kaki diabetes adalah kelainan tungkai kaki bawah akibat diabetes melitus yang tidak terkendali. Kelainan kaki diabetes melitus dapat disebabkan adanya gangguan pembuluh darah, gangguan persyarafan dan adanya infeksi. Kaki diabetes melitus yang tidak dirawat dengan baik akan mudah mengalami luka, dan cepat berkembang menjadi ulkus ganggren dan tidak ditanggulangi. Beberapa penelitian di Indonesia melaporkan bahwa angka kematian ulkus gangren pada penyandang diabetes melitus berkisar 17\%-32\%, sedangkan angka laju amputasi berkisar antara 15\%-30\%. Para ahli diabetes memperkirakan $\quad 1 / 2 \quad$ sampai $3 / 4 \quad$ kejadian amputasi dapat dihindarkan dengan perawatan kaki yang baik. (Fakultas Kedokteran UI, 2008).

\section{a. Gangguan Pembuluh Darah}

Keadaan hiperglikemia yang terus menerus akan mempunyai dampak pada kemampuan pembuluh darah tidak berkontraksi dan relaksasi berkurang. Hal ini mengakibatkan sirkulasi darah tubuh menurun, terutama kaki, dengan gejala antara lain:

1. Sakit pada tungkai bila berdiri, berjalan dan melakukan kegiatan fisik 
2. Jika diraba kaki terasa dingin, tidak hangat

3. Rasa nyeri kaki pada waktu istirahat dan malam hari

4. Sakit pada telapak kaki setelah berjalan

5. Jika luka sukar sembuh

6. Pemeriksaan tekanan nadi kaki menjadi kecil atau hilang

7. Perubahan warna kulit, kaki tampak pucat atau kebiru-kebiruan

\section{b. Gangguan Persyarafan (Neuropati)}

Neuropati akan menghambat signal, rangsangan atau terputusnya komunikasi dalam tubuh. Syaraf pada kaki sangat penting dalam menyampaikan pesan ke otak, sehingga menyadarkan kita akan adanya bahaya pada kaki, misalnya kena paku atau benda-benda panas. Kaki diabetes dengan neuropati akan mengalami gangguan sensorik, motorik dan otonomik. Neuropati sensorik ditandai dengan perasaan kebal (parastesia), kurang berasa (hipestesia) terutama ujung kaki terhadap rasa panas dan sakit, kadang disertai pegal dan nyeri di kaki. Neuropati motorik ditandai dengan kelemahan sistem otot, deformitas kaki (charcot), ibu jari seperti palu (hammer toe), sulit mengatur keseimbangan tubuh. Gangguan syaraf otonomik kulit kaki akan terlihat kering, pecah dan tidak ada keringat.

\section{c. Infeksi}

Penurunan sirkulasi darah kaki menghambat proses penyembuhan luka, akibatnya kuman masuk kedalam luka dan terjadi infeksi. Peningkatan kadar gula darah akan menghambat kerja leukosit dalam mengatasi infeksi, luka menjadi ulkus gangren dan terjadi perluasan infeksi sampai ketulang (osteomielitis), bila tidak diketahui dan ditanggulangi. Kaki yang mengalami ulkus ganggren luas sulit untuk diatasi, yang memerlukan tindakan amputasi.

\section{Diabetes Melitus (DM) Type II}

Yaitu Diabetes yang tergantung insulin.Diabetes Melitus Tipe 2 terjadi akibat penurunan sensitivitas terhadap insulin (resistensi insulin) atau akibat penurunan jumlah produksi insulin. Diabetes Melitus Tipe 2 sering ditemukan pada usia dewasa obesitas meskipun dapat terjadi pada semua umur, ketosis jarang terjadi kecuali dalam kedaan stres atau mengalami infeksi.
Dalam Diabetes Melitus Tipe 2, pankreas dapat menghasilkan cukup jumlah insulin untuk metabolisme glukosa (gula), tetapi tubuh tidak mampu untuk memanfaatkan secara efisien. Seiring waktu, penurunan produksi insulin dan kadar glukosa darah meningkat. Diabetes mellitus sebelumnya dikatakan diabetes tidak tergantung insulin atau diabetes pada orang dewasa.Ini adalah istilah yang digunakan untuk individu yang relatif terkena diabetes (bukan yang absoult) defisiensi insulin.Orang dengan jenis diabetes ini biasanya resisten terhadap insulin.Ini adalah diabetes sering tidak terdiagnosis dalam jangka waktu yang lama karena hiperglikemia ini sering tidak berat cukup untuk memprovokasi gejala nyata dari diabetes.Namun demikian, pasien tersebut adalah risiko peningkatan pengembangan komplikasi macrovascular dan mikrovaskuler.Faktor yang diduga menyebabkan terjadinya resistensi insulin dan hiperinsulinemia ini adalah adanya kombinasi antara kelainan genetik, obesitas, inaktifitas, faktor lingkungan dan faktor makanan (Adhi, 2011).

\section{Senam Kaki Diabetes}

Senam kaki adalah kegiatan yang dilakukan oleh pasien DM untuk mencegah terjadinya luka dan membantu melancarkan peredaran darah pada kaki.Senam kaki dapat membantu memperbaiki sirkulasi darah dan memperkuat otot-otot kecil kaki dan mencegah terjadinya kelainan bentuk kaki (Sumosardjuno, 2007).

Kaki diabetes adalah kelainan tungkai kaki bawah akibat diabetes melitus yang tidak terkendali.Kelainan kaki diabetes dapat disebabkan adanya gangguan pembuluh darah, gangguan persyarafan dan adanya infeksi. Kaki diabetes melitus yang tidak dirawat dengan baik akan mudah mengalami luka, dan cepat berkembang menjadi ulkus ganggren dan tidak ditanggulangi.

Kaki diabetes mengalami gangguan sirkulasi darah dan neuropati dianjurkan untuk melakukan latihan jasmani atau senam kaki sesuai dengan kondisi kemampuan tubuh. Senam kaki dapat membantu memperbaiki sirkulasi darah dan memperkuat otot-otot kecil kaki dan mencegah terjadinya kelainan bentuk kaki (deformiotas).Selain itu dapat meningkatkan kekuatan otot betis dan otot paha (Gastrocnemeus, Hamsring, Quadriceps), 
dan juga mengatasi keterbatasan gerak sendi (Limitiation of joint mobility).

\section{Perawatan Kaki Diabetes}

Penderita DM beresiko terhadap ulkus diabetik karena : sirkulasi darah kaki kurang baik, indera rasa kedua kaki berkurang sehingga kaki mudah terluka, daya tahan tubuh terhadap infeksi menurun.

\section{Perawatan Yang Harus Dilakukan Pada Pasien Kaki Diabetes:}

1. Periksa kaki setiap hari, apakah ada kulit retak, melepuh, luka, perdarahan. Gunakan cermin untuk melihat bagian bawah kaki, atau minta bantuan orang lain untuk memeriksa.

2. Bersihkan kaki setiap hari pada waktu mandi dengan air bersih dan sabun mandi. Bila perlu gosok kaki dengan sikat lunak atau batu apung. Keringkan kaki dengan handuk bersih, lembut, yakinkan daerah sela-sela jari kaki dalam keadaan kering, terutama sela jari ketigakeempat dan keempat-kelima.

3. Berikan pelembab atau lotion pada daerah kaki yang kering, tetapi tidak pada sela-sela jari kaki. Pelembab gunanya untuk menjaga agar kulit tidak retak.

4. Gunting kuku kaki lurus mengikuti bentuk normal jari kaki, tidak terlalu pendek atau terlalu dekat dengan kulit, kemudian kikir agar kuku tidak tajam. Bila penglihatan kurang baik minta bantuan orang lain untuk memotong kuku atau mengikir kuku setiap dua hari sekali. Hindarkan terjadi lukan pada jaringan sekitar kuku. Bila kuku keras sulit untuk dipotong, rendam kaki dengan air hangat kuku (37 C) selama kurang lebih 5 menit, bersihkan dengan sikat kuku, sabun air bersih. Bersihkan kuku setiap hari pada waktu mandi an berikan cream pelembab kuku.

5. Memakai alas kaki sepatu atau sandal untuk melindungi kaki agar tidak terjadi luka, juga didalam rumah.

6. Gunakan sepatu atau sandal yang baik yang sesuai untuk ukuran dan enak untuk dipakai, dengan ruang dalam sepatu yang cukup untuk jari-jari. Pakailah kaus/stoking yang pas dan bersih terbuat dari bahan yang mengandung katun.

7. Periksa sepatu sebelum dipakai, apakah ada kerikil, benda-benda tajam seperti jarum dan duri. Lepas sepatu setiap 4-6 jam serta pergerakan pergelangan dan jari-jari kaki agar sirkulasi darah tetap baik terutama pada pemakaina sepatu baru.

8. Bila ada luka kecil, obati luka dan tutup dengan pembalut bersih. Periksa apakah ada tanda-tanda radang.

9. Segera ke dokter bila kaki mengalami luka.

10.Periksakan kaki kedokter secara rutin.

\section{Tujuan Senam Kaki Diabetes}

1. Memperbaiki sirkulasi darah.

2. Mencegah terjadinya komplikasi lanjut pada pasien DM.

3. Memperkuat otot-otot kecil.

4. Mencegah terjadinya kelainan bentuk kaki.

5. Meningkatkan kekuatan otot betis dan paha.

6. Mengatasi keterbatasan gerak sendi.

\section{Indikasi Dan Kontraindikasi Senam Kaki}

\section{Diabetes}

1. Indikasi

Senam kaki dapat diberikan pada seluruh pasien DM dengan tipe 1 maupun tipe 2 . Namun sebaiknya diberikan sejak pasien di diagnose menderita DM sebagai tindakan pencegahan dini.

2. Kontra indikasi

1) Klien mengalami perubahan fungsi fisiologi seperti dipsnu/ nyeri dada.

2) Orang yang depresi, khawatir atau cemas.

\section{Prosedur Pelaksanaan Senam Kaki}

1. Jika dilakukan dalam posisi duduk maka posisikan pasien duduk tegak di atas kursi dengan kaki tidak menyentuh lantai (kaki mengambang).

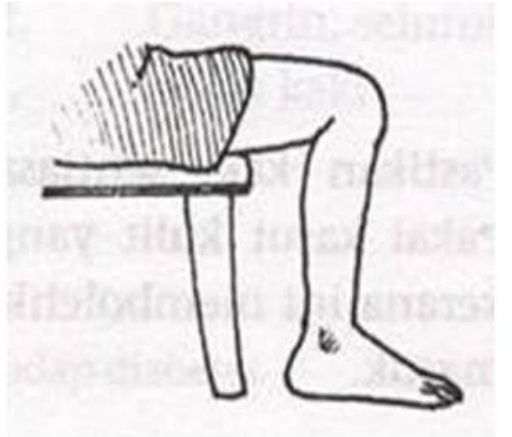

2. Dengan meletakkan tumit dilantai, jarijari kedua belah kaki diluruskan ke atas lalu dibengkok kembali ke bawah seperti cakar ayam sebanyak 10 kali. 


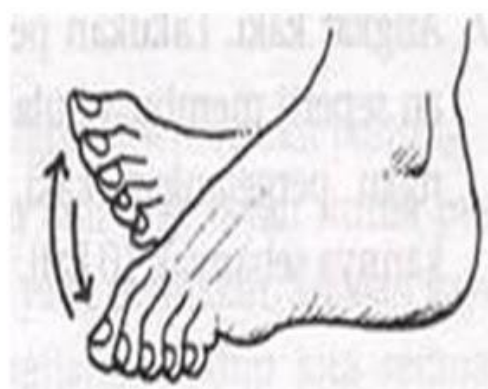

3. Dengan meletakkan tumit salah satu kaki di lantai, angkat telapak kaki ke atas. Pada kaki lainnya ,jari-jari kaki diletakkan di lantai dengan tumit. kaki di angkat ke atas. Cara ini dilakukan bersamaan pada kaki kiri dan kanan secara bergantian selama 10 kali.

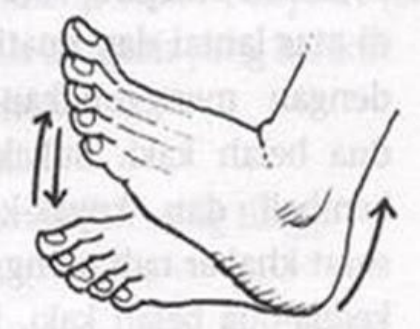

4. Tumit kaki diletakkan di lantai bagian ujung diangkat ke atas dan buat gerakan memutar dengan pergerakan pada pergelangan kaki sebanyak 10 kali.

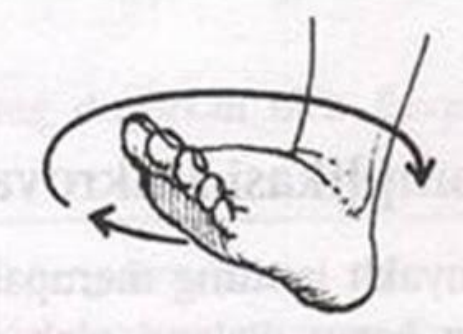

5. Jari-jari kaki dilakukan dilantai. Tumit diangkat dan buat gerakan memutar dengan pergerakan pada pergelangan kaki sebanyak 10 kali.

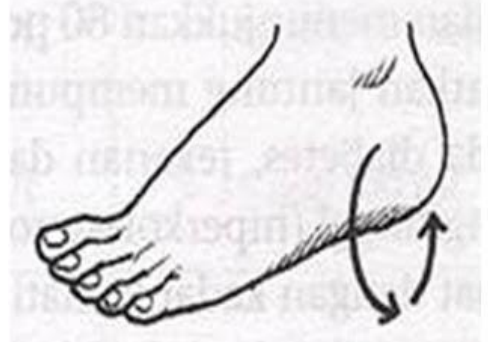

6. Angkat salah satu lutut kaki dan luruskan. Gerakkan jari-jari kedepan turunkan kembali secara bergantian kekiri dan kekanan sebanyak 10 kali.
7. Luruskan salah kaki diatas lantai kemudian angkat kaki tersebut dan gerakan ujung jari kaki kearah wajah lalu turunkan kembali ke lantai.

8. Angkat kedua kaki lalu luruskan. Ulangi langkah ke 7, namun gunakan kedua kaki secara bersamaan. Ulangi sebanyak 10 kali.

9. Angkat kedua kaki dan luruskan, pertahankan posisi tersebut. Gerakan pergelangan kaki kedepan dan kebelakang.

10. Luruskan salah satu kaki dan angkat, putar kaki pada pergelangan kaki, tuliskan pada udara dengan kaki dari angka 0-9 lakukan secara bergantian (yang bergerak bagian paha).

11. Letakkan sehelai Koran dilantai. Bentuk kertas itu menjadi seperti bola dengan kedua belah kaki
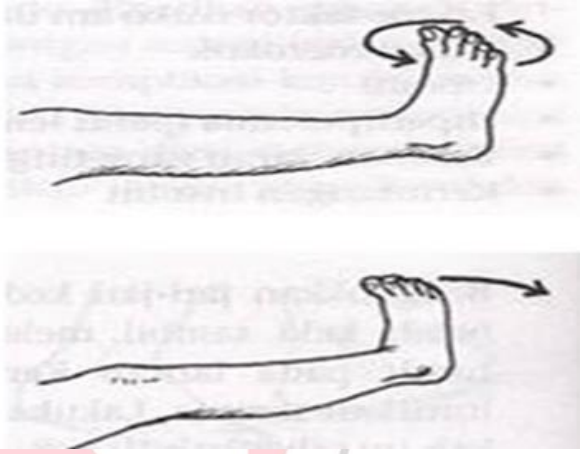

12. Lalu robek Koran menjadi 2 bagian, pisahkan kedua bagian Koran.

13. Sebagian Koran disobek-sobek menjadi kecil-kecil dengan kedua kaki

14. Pindahkan kumpulan sobekan-sobekan tersebut dengan ke-2 kaki, lalu letakkan sobekan kertas pada bagian kertas yang utuh, bungkus semuanya dengan kedua kaki menjadi bentuk bola.

\section{METODOLOGI}

Jenis Penelitian deskriptif dengan kemampuan menggambarkan dan menguraikan masalah yang ada yaitu untuk mengetahui Gambaran Pengetahuan Pasien Diabetes Melitus Tipe 2 Tentang Senam Kaki Pada Diabetes di Lingkungan XXIV Pekan Labuhan Kecamatan Medan Labuhan Tahun 2017.

Waktu dalam penelitian ini dilaksanakan pada bulan April - Mei Tahun 2017.Populasi dalam penelitian ini adalah Seluruh penderita DM Tipe 2 berjumlah 10 orang yang di Lingkungan XXIV Pekan 
Labuhan Kecamatan Medan Labuhan Medan pada bulan April - Mei Tahun 2017. Sampel yang di ambil dalam penelitian ini adalah seluruh penderita DM Tipe 2 yang ada di Lingkungan XXIV Pekan Labuhan Kecamatan Medan Labuhan Tahun 2017 sebanyak 10 orang dengan menggunakan tehnik total sampling.

\section{HASIL}

Tabel 1. Distribusi Frekuensi Responden Berdasarkan Umur Pasien Diabetes Melitus Tipe 2 Tentang Senam Kaki Pada Diabetes di Lingkungan XXIV Pekan Labuhan Kecamatan Medan Labuhan Tahun 2017.

\begin{tabular}{clcc}
\hline No & Umur (Tahun) & (F) & $\mathbf{( \% )}$ \\
\hline 1. & $40-44$ & 1 & 10 \\
\hline 2. & $45-49$ & 2 & 20 \\
\hline 3. & $50-54$ & 2 & 20 \\
\hline 4. & $55-59>60$ & 2 & 20 \\
5. & & 3 & 30 \\
\hline & Total & $\mathbf{1 0}$ & $\mathbf{1 0 0}$
\end{tabular}

Berdasarkan tabel/diatas dapat dilihat bahwa dari 10 responden mayoritas berumur $>60$ tahun keatas sebanyak 3 responden (30\%) dan minoritas berumur 40-44 sebanyak masing-masing 1 responden $(10 \%)$.

Tabel 2. Distribusi Frekuensi Responden Berdasarkan Pendidikan Pasien Diabetes Melitus Tipe 2 Tentang Senam Kaki Pada Diabetes di Lingkungan XXIV Pekan Labuhan Kecamatan Medan Labuhan Tahun 2017.

\begin{tabular}{lccc}
\hline No & $\begin{array}{c}\text { Tingkat } \\
\text { Pendidikan }\end{array}$ & (f) & $(\mathbf{\% )}$ \\
\hline 1 & SD & 4 & 40 \\
\hline 2. & SMP & 3 & 30 \\
\hline 3. & SMA & 2 & 20 \\
\hline 4. & Perguruan Tinggi & 1 & 10 \\
\hline & Total & $\mathbf{1 0}$ & $\mathbf{1 0 0}$ \\
\hline
\end{tabular}

Berdasarkan tabel diatas dapat dilihat dari 10 responden mayoritas berpendidikan SD sebanyak 4 responden (40\%) dan minoritas berpendidikan Perguruan Tinggi sebanyak 1 responden (10\%).

Tabel 3. Distribusi Frekuensi Responden Berdasarkan Sumber Informasi Pasien Diabetes Melitus Tipe 2 Tentang Senam Kaki Pada Diabetes di Lingkungan XXIV Pekan Labuhan Kecamatan Medan Labuhan Tahun 2017.

\begin{tabular}{clcc}
\hline No. & Sumber Informasi & (f) & $(\boldsymbol{\%})$ \\
\hline 1. & Media Cetak & 0 & 0 \\
\hline 2. & Tenaga Kesehatan & 2 & 20 \\
\hline 3. & Media Elektronik & 2 & 20 \\
\hline 4. & $\begin{array}{l}\text { Tidak Memperoleh } \\
\text { Sumber Informasi }\end{array}$ & 6 & 60 \\
\hline \multicolumn{1}{c}{ Total } & $\mathbf{1 0}$ & $\mathbf{1 0 0}$ \\
\hline
\end{tabular}

Berdasarkan tabel diatas dapat dilihat dari 10 responden mayoritas yang tidak memperoleh informasi sebanyak 6 responden (60\%) dan ada masyarakat yang menderita diabetes mellitus tidak dapat informasi dari media cetak.

Tabel 4. Distribusi Frekuensi Responden Berdasarkan Pekerjaan Pasien Diabetes Melitus Tipe 2 Tentang Senam Kaki Pada Diabetes di Lingkungan XXIV Pekan Labuhan Kecamatan Medan Labuhan Tahun 2017.

\begin{tabular}{clcc}
\hline No & Pekerjaan & (f) & $(\boldsymbol{\%})$ \\
\hline 1. & IRT & 5 & 50 \\
\hline 2. & Nelayan & 3 & 30 \\
\hline 3. & Wiraswasta & 2 & 20 \\
\hline & Total & $\mathbf{1 0}$ & $\mathbf{1 0 0}$ \\
\hline
\end{tabular}

Dari tabel diatas dapat dilihat dari 10 responden mayoritas bekerja sebagai IRT sebanyak 5 responden (50\%) dan minoritas bekerja sebagai wiraswasta sebanyak 2 responden (20\%).

Tabel 5. Distribusi Frekuensi Responden Berdasarkan Pengetahuan Pasien Diabetes Melitus Tipe 2 Tentang Senam Kaki Pada Diabetes di Lingkungan XXIV Pekan Labuhan Kecamatan Medan Labuhan Tahun 2017.

\begin{tabular}{clcc}
\hline No. & Pengetahuan & (f) & $(\mathbf{\%})$ \\
\hline 1. & Baik & 2 & 20 \\
\hline 2 & Cukup & 3 & 30 \\
\hline 3 & Kurang & 5 & 50 \\
\hline & Total & $\mathbf{1 0}$ & $\mathbf{1 0 0}$ \\
\hline
\end{tabular}

Berdasarkan tabel diatas dapat dilihat tingkat pengetahuan responden mayoritas berpengetahuan kurang berjumlah 5 responden (50\%) dan minoritas berpengetahuan baik berjumlah 2 responden $(20 \%)$.

\section{PEMBAHASAN}

Berdasarkan hasil penelitian yang telah dilakukan terhadap 10 responden yang diteliti menunjukkan bahwa Pengetahuan Pasien Diabetes Melitus Tipe 2 Tentang Senam Kaki Pada Diabetes di Lingkungan 
XXIV Pekan Labuhan Kecamatan Medan Labuhan Tahun 2017 mayoritas berumur > 60 tahun keatas sebanyak 3 responden $(30 \%)$ dan minoritas berumur 40-44 sebanyak masing-masing 1 responden $(10 \%)$.

Umur mempengaruhi terhadap daya tangkap dan pola pikir seseorang. Semakin bertambah usia akan semakin berkembang pula daya tangkap dan pola pikirnya, sehingga pengetahuan yang diperolehnya semakin membaik. Pada usia madya, individu akan lebih berperan aktif dalam masyarakat dan kehidupan sosial serta lebih banyak melakukan persiapan demi suksesnya upaya menyesuaikan diri menuju usia tua, selain itu orang usia madya akan lebih banyak menggunakan banyak waktu untuk membaca. Kemampuan intelektual, pemecahan masalah, dan kemampuan verbal dilaporkan hampir tidak ada penurunan pada usia ini menurut (Notoatmodjo, 2007).

Menunjukkan bahwa Pengetahuan Pasien Diabetes Melitus Tipe 2 Tentang Senam Kaki Pada Diabetes di Lingkungan XXIV Pekan Labuhan Kecamatan Medan Labuhan Tahun 2017 dapat dilihat mayoritas

Sumber Informasi adalah segala sesuatu yang menjadi perantara dalam penyampaian informasi, merangsang pikiran dan kemampuan . Sumber informasi akan mempengaruhi bertambahnya pengetahuan seseorang terhadap suatu hal sehingga informasi yang di peroleh dapat diadopsi secara keseluruhan atau hanya sebagian (Notoatmodjo, 2007).

Menurut penulis, semakin banyak informasi yang di peroleh penderita DM tentang senam kaki diabetik dan manfaat dari senam kaki diabetik maka semakin tinggi pula keinginan Pasien Diabetes Melitus Tipe 2 Tentang Senam Kaki Pada Diabetes.

Responden mayoritas bekerja sebagai IRT sebanyak 5 responden (50\%) dan minoritas bekerja sebagai wiraswasta sebanyak 2 responden (20\%).

Adapun faktor-faktor yang mempengaruhi pengetahuan berdasarkan teori Mubarak (2011) Tidak dapat dipungkiri bahwa semakin tinggi pendidikan seseorang, semakin muda pula mereka menerima informasi, dan pada akhirnya pengetahuan yang dimilikinya akan semakin banyak, pekerjaan berarti lingkungan pekerjaan berpendidikan SD sebanyak 4 responden (40\%) dan minoritas berpendidikan Perguruan Tinggi sebanyak 1 responden (10\%).

Pendidikan adalah suatu usaha untuk mengembangkan kepribadian dan kemampuan di dalam dan di luar sekolah dan berlangsung seumur hidup. Pendidikan mempengaruhi proses belajar, makin tinggi pendidikan seeorang makin mudah orang tersebut untuk menerima informasi. Dengan pendidikan tinggi maka seseorang akan cenderung untuk mendapatkan informasi, baik dari orang lain maupun dari media massa (Notoatmodjo, 2007).

Penelitian ini sesuai dengan Notoadmodjo (2007), pendidikan adalah kegiatan atau usaha untuk menyampaikan pesan kesehatan pada masyarakat, kelompok atau individu. Semakin tinggi pendidikan seseorang maka semakin mudah menerima informasi dan semakin bagus pula pengetahuan yang dimiliki. Mayoritas yang tidak memperoleh informasi sebanyak 6 responden (60) dan minoritas memperoleh informasi dari tenaga kesehatan dan media elektronik sebanyak 2 responden (20\%).

dapat membuat seseorang memperoleh pengalaman dan pengetahuan, baik secara langusung maupun tidak langsung, umur berarti dengan bertambahnya umur seseorang akan mengalami perubahan aspek fisik dan psikologis (mental).

Dari hasil tingkat pengetahuan mayoritas berpengetahuan kurang berjumlah 5 responden (50\%) dan minoritas berpengetahuan baik berjumlah 2 responden (20\%).

Hal ini sesuai pendapat Notoadmodjo (2007) bahwa Pengetahuan merupakan hasil dari tahu dan ini setelah orang melakukan pengindraan terhadap obyek tertentu. Pengindraan terjadi melalui panca indra manusia, yakni indra penglihatan,pendengaran, penciuman, rasa dan raba. Sebagian besar pengetahuan manusia diperoleh melalui mata dan telinga.Pengukuran pengetahuan dapat dilakukan dengan wawancara atau angket yang menanyakan tentang isi materi yang ingin di ukur dari subjek penelitian atau responden.

Demikian hasil penelitian ini bahwa dari 10 responden ditemukan 10 orang berpengetahuan baik yang artinya 
menggambarkan tingkat kualitas pengetahuan lansia mengenai senam kaki diabetik belum pada taraf yang di inginkan.Hal ini disebabkan karena kurangnya kemampuan atau motivasi penderita DM mencari pengetahuan tentang senam kaki diabetik.

\section{KESIMPULAN}

Berdasarkan hasil penelitian yang telah dilakukan pada bulan April - Mei 2017 di Lingkungan XXIV Pekan Labuhan Kecamatan Medan Labuhan, maka diperoleh kesimpulan sebagai berikut:

Hasil penelitian yang dilakukan di Lingkungan XXIV Pekan Labuhan Kecamatan Medan Labuhan tentang Senam Kaki Pada Diabetes terhadap Pasien Diabetes Melitus Tipe 2 tergolong berpengetahuan berpengetahuan kurang berjumlah 5 responden $(50 \%)$ dan minoritas berpengetahuan baik berjumlah 2 responden (20\%).Pasien Diabetes Melitus Tipe 2 yang mayoritas berpendidikan SD sebanyak 4 responden (40\%). Jadi semakin tinggi pendidikan seseorang maka semakin luas pula pengetahuannya dan juga motivasi penderita Diabetes Melitus Tipe 2 untuk mencari berbagai sumber informasi tentang pengobatan klien yang mengalami Diabetes Melitus Tipe 2 (DM). Banyak penderita Diabetes Melitus Tipe 2 di masyarakat menganggap penyakit Diabetes Melitus Tipe 2 adalah hal yang biasa dan tidak perlu berobat ke tenaga kesehatan padahal menurut (STPTM Dinas Kesehatan Propinsi Sumatera Utara, 2008). Penyakit Diabetes Melitus Tipe 2 di Medan, sampai September 2009 merupakan penyakit dengan penderita terbanyak, yang terus mengalami peningkatan jumlahnya. Yang mana sampai menyebabkan ulkus ganggren jika penderita Diabetes Melitus Tipe 2 tidak di cegah atau di tanggulangi dengan baik.

\section{SARAN}

\section{Institusi Pendidikan Keperawatan}

Hendaknya intitusi pendidikan keperawatan secara terus menerus memberikan pengajaran kepada mahasiswa/i khususnya tentang senam kaki diabetik sehingga mahasiswa/i dapat mengaplikasikan didalam masyarakat.

\section{Pelayanan Kesehatan}

Pelayanan kesehatan diharapakan dapat memberikan informasi kepada Pasien Diabetes Melitus Tipe 2 Tentang Senam Kaki Pada Diabetes sehingga penderita juga ikut berperan dalam penyembuhan klien khususnya pencegahan ulkus ganggren dirumah.

3. Bagi Penderita Diabetes Melitus Tipe 2 Diharapkan kepada Pasien Diabetes Melitus Tipe 2 agar dapat menambah pengetahuannya tentang Senam Kaki Pada Diabetes, baik manfaat, tujuan, dan prosedur pelaksanaanya. Sehingga penderita Diabetes Melitus Tipe 2 dapat melatih otot otot pada kaki dan sistem persarafan untuk membatu sirkulasi darah agar baik.

\section{Peneliti selanjutnya}

Diharapkan bagi penelitian selanjutnya agar dapat melakukan penelitian yang lebih mendalam/spesifik lagi tentang Gambaran Pengetahuan Pasien Diabetes Melitus Tipe 2 Tentang Senam Kaki Pada Diabetes di Lingkungan XXIV Pekan Labuhan Kecamatan Medan Labuhan Tahun 2017.

\section{DAFTAR PUSTAKA}

Adhisty, Karolin. (2011). Pengaruh Senam Diabetes Terhadap Penurunan Kadar Gula Darah sewaktu Pada DM Tipe II. Skripsi Strata Satu Ilmu Keperawatan, Program Studi ilmu keperawatan Fakultas Kedokteran Universitas Sriwijaya.

Akhtiyo. (2009). Gambaran klinis hipoglikemia pada pasien diabetes melitus rawat inap di unit penyakit dalam rsup $d r$ sardjito yogyakarta. Yogyakarta: acta medica Indonesiana.

American Diabetes Association. (2010). Diabetes Care. Akses Online tanggal $26 \quad$ Maret 2015 pukul 16.15 WIB. URL : http://www.nc bi.nlm.nih.gov/pmc/articles/PMC 2992225/?tool=pmcentrez.

Anneahira. (2011) . Senam Kaki Diabetes. Akses Online Tanggal 27 maret 2015 20.35 WIB URL : http://www.anneahira.com/ senamkaki-diabetes.htm 
Arikunto, Suharsimi, (2010). Prosedur Penelitian, (Edisi Revisi). Jakarta: Rineka Cipta.

Dinkes Kota Medan, (2009). Profil Kesehatan Sumatra Utara. Medan :Dinkes Kota Medan 2009.

FKUI. (2008). Penatalaksanaan Diabetes Mellitus, Ed. Kedua. Jakarta : FKUI

Hasdianah, (2012). Mengenal diabetes melitus. Yogyakrta : Nuha Medika.

Julian, (2010). Pengaruh

Senam Kaki terhadapPeningkatan Sirkulasi Darah kaki pada Pasien Penderita Diabetes Mellitus di RSUP H.A.M. Medan: JurnalPenelitian.

Nursalam, (2012). Konsep dan penerapan metodologi penelitian ilmu kesehatan pedoman skripsi tesis dan instrumen penelitian keperawatan . Jakarta: salemba medika

Notoadmodjo, (2007). Promosi Kesehatan Dan Ilmu Prilaku. Jakarta : Rineka Cipta

Notoadmodjo, (2010). Metodologi Penelitian Kesehatan. Jakarta : EGC

Ramaiah. (2008). Diabetes: Cara Mengetahui Gejala Diabetes dan Mendeteksinya Sejak Dini. Jakarta: PT Bhuana Ilmu Populer.
Setiadi. (2007). Konsep dan penulisan Riset Keperawatan. Jakarta : EGC.

Sugiyono. (2007). Metode penelitian pendidikan pendekatan kuantitatif, kualitati dan R\&D. Bandung: Alfabeta.

Sukarmin, (2008). Askep pada pasien dengan gangguan eksokrin dan endokrin pada pankreas. Yogyakarta : Graha ilmu.

Sumosardjuno, (2007). Sehat dan Bugar, Petunjuk Praktis Berolahraga yang Benar. Jakarta : PT. Gramedia Pustaka Utama.

Wawan dan Dewi, (2010). Teori \& Pengukuran, Sikap, dan Perilaku Manusia. Penerbit Nuha Yogyakarta : Medika.

WHO, (2009). Diabetes factsheet. Department of Sustainable Development and Healthy Environments.

Wibisono, (2009). Senam Khusus Untuk Pe nderita Diabetes. Akses Online Tanggal 15 Agustus 2011. URL : http://senamkaki.com.

Yudhi. (2009). Senam Kaki. Akses Online tanggal 27 maret 2015 pukul 20.30 WIB . URL :

http://www.kesad.mil.id/content/senamkaki. 